\title{
Comparative evaluation of mechanised and manual threshing options for Amankwatia and AGRA rice varieties in Ghana
}

\author{
Shadrack Kwadwo Amponsah, ${ }^{1}$ Ahmad Addo, ${ }^{1}$ Komla Dzisi, ${ }^{1}$ Jean Moreira, ${ }^{2}$ Sali Atanga Ndindeng ${ }^{2}$ \\ ${ }^{1}$ Department of Agricultural Engineering, KNUST, Kumasi, Ghana; ${ }^{2}$ Africa Rice Centre, Cotonou, Benin
}

\begin{abstract}
Performance of a Yanmar DB 1000 mechanised paddy thresher was comparatively assessed against manual threshing by impact method using a locally-made wooden box for Amankwatia and AGRA rice varieties under farmer's field conditions at Nobewam in the Ashanti Region of Ghana. The mechanised thresher was evaluated at various threshing drum speeds $(550 \mathrm{rpm}, 600 \mathrm{rpm}$ and $650 \mathrm{rpm})$ and feeding rates $\left(200 \mathrm{kgh}^{-1}, 400 \mathrm{kgh}^{-1}\right.$ and $\left.600 \mathrm{kgh}^{-1}\right)$. Results showed that threshing was satisfactory at grain moisture content between $16.9 \%$ w.b. and $18.0 \%$ w.b. for both rice varieties. Threshing efficiency increased from $94.6 \%$ to $95.8 \%$ with no significant difference observed whereas cleaning efficiency decreased significantly from $84.2 \%$ to $81.6 \%$ with increasing feed rate irrespective of rice variety. Again, threshing efficiency increased with increasing drum rotational speed, irrespective of feed rate and rice variety. Percentage broken grain and grain loss both increased with increasing peripheral drum speed and paddy feed rate irrespective of rice variety. Average fuel consumption, physical energy requirement and threshing capacity increased significantly with increasing drum speed and feed rate. Crop moisture content and shattering ability influenced the threshing efficiency, threshing capacity, grain loss, broken grain, fuel and physical energy requirement at threshing. AGRA rice variety generally
\end{abstract}

Correspondence: Shadrack Kwadwo Amponsah, Department of Agricultural Engineering, KNUST, Kumasi, Ghana.

E-mail: skamponsah@hotmail.com

Key words: Amankwatia; drum speed; efficiency; feed rate; mechanised; threshing.

Acknowledgements: the authors wish to acknowledge the financial support from the Africa Rice Centre, through the Support to Agricultural Research for Development of Strategic Crops in Africa (SARD-SC) project. We wish to also express our gratitude to the field staff of the CSIR-Crops Research Institute, Kumasi, Ghana and the rice farmers at Nobewam, Ashanti Region, Ghana who played a part in making the study a success.

Received for publication: 14 February 2017.

Accepted for publication: 8 May 2017.

(C) Copyright S.K. Amponsah et al., 2017

Licensee PAGEPress, Italy

Journal of Agricultural Engineering 2017; XLVIII:684

doi:10.4081/jae.2017.684

This article is distributed under the terms of the Creative Commons Attribution Noncommercial License (by-nc 4.0) which permits any noncommercial use, distribution, and reproduction in any medium, provided the original author(s) and source are credited. performed better than Amankwatia under both mechanical and manually threshing methods. Mechanised threshing was significantly better at reducing grain loss and physical energy demand whilst yielding over $200 \%$ higher threshing capacity than manual threshing by impact using the wooden box. Mechanised threshing was financially rewarding, yielding over $500 \%$ higher profit margin than the manual threshing option. Further research on optimum crop moisture content for improved threshing of different rice varieties is suggested.

\section{Introduction}

Rice is important to Ghana's economy and agriculture, accounting for nearly $15 \%$ of the gross domestic product (ISSER, 2000). The crop has become the second most important food staple after maize and its consumption keeps increasing as a result of population growth, urbanisation and change in consumer habit (MoFA, 2009). reported that between 2005 and 2010, Ghana ranked among the top 50 rice producers worldwide, dropping out of the list only in 2007. In addition to being a staple food mainly for high income urban populations, rice is also an important cash crop in the communities in which it is produced (Angelucci et al., 2013). Ghana depends heavily on imported rice (Campbell et al., 2009; Angelucci et al., 2013) with the crop constituting 58\% of all cereal imports (Osei-Asare, 2010). It is estimated that the country imports between US\$200 million and US\$400 million worth of rice annually which accounts for more than $50 \%$ of all rice consumed in the country. The amount is said to be one of the major factors that swells the country's import bill, greatly affecting foreign exchange (Okine, 2014).

Harvesting and threshing operations are known as crucial and influential processes on quantity, quality and production cost of rice (Alizadeh and Bagheri, 2009; Alizadeh and Allameh, 2013). A report by Osei-Asare (2010) identified inadequate appropriate harvesting technology/equipment as a major problem that may constrain rice production in Ghana. This has made it difficult for area expansion as far as production is concerned. Khan (1971) and IDRC (1976) added that the problem of harvesting and threshing is worsened with the introduction of more productive rice varieties because of the greater amount of crop that has to be handled. Rice could either be manually or mechanically threshed. In Ghana, threshing is traditionally achieved by beating harvested rice panicles against a wooden box or metal barrel or by beating cut panicles with sticks to detach grains. According to Appiah et al. (2011), the output of these manual threshing methods ranges from $0.01 \mathrm{~kg}$ to $30 \mathrm{~kg}$ of grain per man-hour depending on the variety of rice, condition of rice, the method applied and rice losses recorded. Rickman et al. (2013) also reported that the manual threshing method is popular due to its associated low cost; however, quantitative and qualitative losses can be as high as $20-30 \%$.

Ghana has made serious efforts in the recent past to introduce 
few rice harvesting technologies from Asia to help boost the rice sector (Rickman et al., 2013). Between 2007 and 2010 alone, the government through the Agricultural Engineering Services Directorate, MoFA imported 30 rice reapers, 30 rice threshers and 39 rice combines to be supplied to smallholder farmers across the country (MoFA SRID, 2011). Unfortunately, these efforts have not really achieved expected results because, aside the fact that such machinery are unaffordable and in most cases unavailable to these resource-poor farmers, they are not well suited to local conditions (Osei-Asare, 2010). Hand and pedal threshers (500 kgd-1 capacity) have been widely adopted in Burkina Faso, Guinea, Liberia, Madagascar and Sierra Leone. According to Rickman et al. (2013), these threshers can now be built locally for use by small-scale farmers and seed producers. However, due to the high amount of physical energy required to operate these threshers, there has been an increased desire within the region for mechanised threshers. Similarly in Ghana, the low quality of rice produced through the use of traditional threshing methods, labour shortage, reduced turn-around time and use of high yielding varieties have forced farmers to shift to mechanised grain threshing (Akolgo et al., 2015).

Since its introduction to Ghana in 2009 from Japan, the Yanmar DB 1000 thresher has only been evaluated on Jasmine 85 rice variety to assess the extent and causes of grain loss (Akolgo et al., 2015). There's the need to further assess the thresher under varying field and crop conditions in comparison to existing manual threshing methods. Such information on technical and economic performances of existing rice threshing systems will not only offer farmers the opportunity to access different mechanisation options but is also crucial in facilitating future improvement on technology design and overall efficiency. This will consequently ensure acceptability and promote better adoption of improved harvesting technologies by smallholder rice farmers. Studies by Špokas et al. (2008) indicated that the design and technological parameters of the threshing apparatus influence grain losses. Ajav and Adejumo (2005) assessed the performance of an Okra thresher by taking moisture content, cylinder speed and feed rate as independent parameter to obtain the maximum threshing efficiency. Research by Gol and Nada (1991) showed that speed of operation and condition of crop are important factors affecting the efficiency of a mechanical threshing or stripping unit. Drum peripheral speed and feed rate has also been found to significantly influence threshing capacity and paddy grain loss (Akolgo et al., 2015; Olaye et al., 2016).

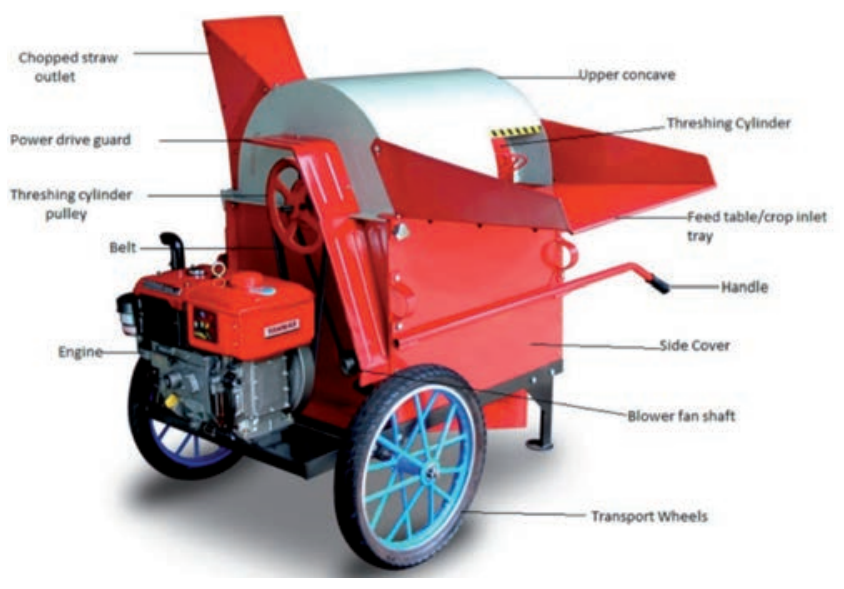

Figure 1. Labelled pictorial view of the Yanmar DB 1000 mechanised rice thresher.

\section{Objectives of study}

The main objective of this study was to evaluate the performances of mechanised and manual threshing methods for two rice varieties under farmer's field conditions. Specific objectives of the study were to: i) assess the effect of drum rotational speed and feed rate on threshing efficiency, cleaning efficiency, threshing (output) capacity and fuel consumption of the mechanised thresher; ii) determine the percentage broken grains, percentage grain loss, threshing capacity and level of drudgery associated with both mechanised and manual rice threshing methods for AGRA and Amankwatia rice varieties; iii) assess the economic feasibility of using the mechanised and manual rice threshing options.

\section{Materials and methods}

\section{Study location and rice variety}

The study was conducted at Nobewam in the Ejisu-Juaben municipality located in the Ashanti Region of Ghana under farmer's field conditions. The field was planted to both Amankwatia and AGRA rice varieties using seedling-transplanting method.

\section{Machine specification}

Figure 1 illustrates a labelled pictorial view the Yanmar DB 1000 mechanised thresher (Yanmar Co., Ltd., Osaka, Japan). Prior to field evaluation, the following technical parameters/condition of the machine were determined; overall dimensions and weights, power source, details of feeding arrangements, details of threshing unit, type of sieve(s), details of fan(s), method of transport and safety arrangements.

Table 1 presents the technical details and specifications of the Yanmar DB 1000 mechanised paddy thresher.

Table 1. Technical specifications of the Yanmar DB 1000 mechanised paddy thresher.

\begin{tabular}{ll}
\hline Parameter & Specification \\
Model & DB 1000 Yanmar paddy thresher \\
Dimensions: length×width×height (mm) & $1034 \times 1200 \times 1462$ \\
\hline Engine model & Diesel engine TF55H-di \\
Engine output $(\mathrm{kW} / \mathrm{rpm})$ & $4.0 / 2200$ \\
\hline Net weight $(\mathrm{kg})$ & 130 \\
Feeding type & Throw-in \\
\hline Feeding desk height (mm) & 944 \\
Threshing teeth type & Swirl \\
\hline Threshing cylinder type & Axial-flow \\
Concave clearance (mm) & $15-25$ \\
\hline Diameter of threshing drum (mm) & 500 \\
Length of threshing drum (mm) & 1000 \\
\hline Shaft rotation speed $(\mathrm{rpm})$ & $550-650$ \\
Cleaning mode & Fan blast \\
\hline Fan type & Agricultural centrifugal type \\
Screen type & Steel square bar \\
\hline Threshing capacity $\left(\mathrm{kgh}^{-1}\right)$ & 1000 \\
\hline
\end{tabular}




\section{Manual threshing}

Paddy was manually threshed by impact method with the help of a locally-made wooden box. The wooden box (both ends open) is square in top cross-section and tapers down to the other square cross-section bottom. A tarpaulin or plastic sheet is usually spread out on the threshing floor and the wooden box placed on it to ensure that grains that will fall outside the box are safely captured. The farmer holds the crop and beats the panicles severally on the inside of the wooden box (Figure 2). Detached grains end up inside the box, which are later collected when the box is full and the threshed crop thrown away.

\section{Crop condition}

The test condition of crop (variety, duration of crop, grain/straw ratio, grain/straw moisture content, grain size, percentage of damaged grain and crop height) were determined using appropriate procedures according to Smith et al. (1994).

\section{Moisture content}

From each harvested field to be threshed, 3 samples of approximately $0.5 \mathrm{~kg}$ each were randomly taken. The samples were placed in sealed plastic containers and taken to the laboratory where the grains and straw were separated by hand. The straw and grains from each sample were kept paired. After weighing with a sensitive electronic scale, the samples were oven dried at $130^{\circ} \mathrm{C}$ for at least $15 \mathrm{~h}$ and then reweighed. The moisture content (\% w.b.) was calculated using Equation 1:

$$
\text { Moisture content }=\frac{\text { weight of wet sample - weight of dry sample }}{\text { weight of wet sample }} \times 100
$$

\section{Grain/straw ratio}

After determining the weight of the dry samples, the result of the paired samples was used to calculate the mean grain/straw ratio using Equation 2:

$$
\text { Grain/straw ratio }=\frac{\text { weight of dry grain }}{\text { weight of dry straw }}
$$

\section{Size of grains}

From a representative sample of the test material, grain and straw were separated by hand and the size (grain diameter and length) of 50 grains measured. The average grain diameter and length was determined using a digital Vernier caliper with an accuracy of $+/-0.02$ $\mathrm{mm}$. Grains were also inspected for damage and the damage calculated as a percentage of the total number of grains sampled.

\section{Machine field test procedure}

With the thresher set up in accordance with the manufacturer's instructions and threshing mechanism properly adjusted, runs were made at various threshing drum speeds ( $550 \mathrm{rpm}, 600 \mathrm{rpm}$ and 650 $\mathrm{rpm})$ and feeding rates $\left(200 \mathrm{kgh}^{-1}, 400 \mathrm{kgh}^{-1}\right.$ and $\left.600 \mathrm{kgh}^{-1}\right)$. For each experimental run, bundles of harvested crop were manually fed into the threshing chamber at uniform rates and the time requirement for threshing was recorded. Any time for stoppages was recorded with the total testing time. Observations on factors affecting the operation of the machine were also recorded together with any adjustments and repairs. At the end of each test run, the machine was operated idle for 2 to $3 \mathrm{~min}$ to clear residue from respective outlets.
A digital tachometer (TA-114) was used to define the various drum speeds (rpm). Tests were carried out to determine the following parameters during threshing; grain quality (rubbish content, damage to grains, grain loss), rate of work (threshing efficiency, cleaning efficiency and output capacity). Fuel consumption and the level of physical energy requirement associated with threshing under each experimental run were also determined as described below.

\section{Grain quality assessment}

For each treatment (variable threshing drum speed and feed rate), three $500 \mathrm{~g}$ rice samples were collected from a larger amount of grain by placing the sample bottle in the stream of grain, which is entering the sacks at the grain outlet. The coning and quartering technique, according to NRI (2000), was used to collect representative samples for grain quality assessment. Whole grains and rubbish were separated by hand in the laboratory. Similarly, threshed grain samples after manual threshing with the wooden box were collected for grain quality assessment.

\section{Damaged/broken grains}

For damaged/broken grains assessment, three samples of 100 grains were randomly taken from the separated grain sample and manually checked for signs of fissure with the help of a magnifying glass. The percentage damaged/broken grain was then calculated using Equation 3.

$$
\text { Broken grains }(\%)=\frac{\text { number of damaged/broken grains }}{\text { total number of grains in sample }} \times 100
$$

\section{Grain loss}

For grain loss assessment, grains collected through thresher main outlet were weighed and recorded as total grain input. All whole, broken and un-threshed grains from sieve and chaff outlets were collected and weight recorded. Scattered and blown grains were recovered by sweeping and gathering grains around the thresher. The percentage grain loss was calculated using Equation 4 according to Smith et al. (1994).

$$
\text { Grain loss }(\%)=\frac{\text { lost grains from chaff and sieve outlet }(\mathrm{kg})}{\text { total grain input }(\mathrm{kg})} \times 100
$$

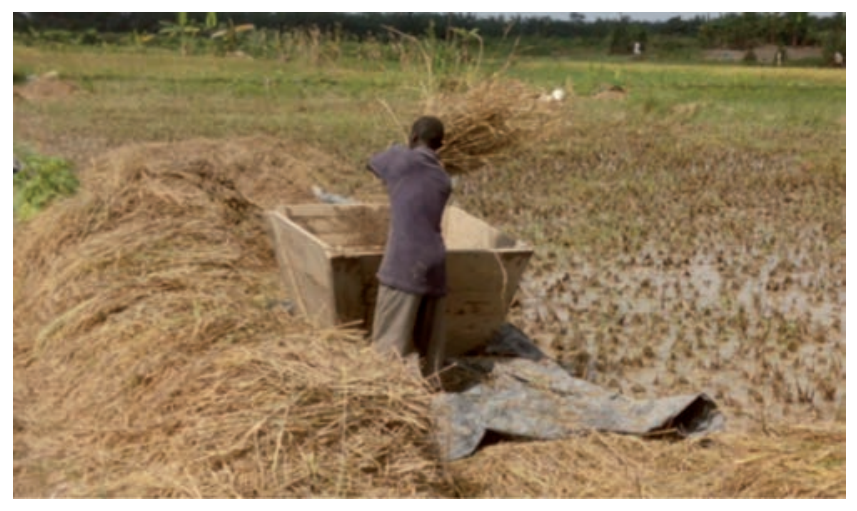

Figure 2. Paddy threshing by impact method using the wooden box. 
For manual threshing, all grains, which fell outside the wooden box, were collected after threshing and loss calculated as a percentage of total grain yields.

\section{Rate of work}

\section{Threshing efficiency}

The net threshed grain received at main outlet with respect to total grain input expressed as percentage by weight is termed as threshing efficiency. The threshing efficiency was calculated using Equation 5 by Smith et al. (1994).

Threshing efficiency $(\%)=100-\left[\frac{\text { unthreshed grains at all outlet per unit time }(\mathrm{kg})}{\text { total grain input }(\mathrm{kg})} \times 100\right]$

\section{Cleaning efficiency}

Cleaning efficiency is the ratio of whole grains to whole material at thresher main outlet per unit time expressed as percentage by weight and was determined using Equation 6.

$$
\text { Cleaning efficiency }(\%)=\frac{\text { whole grains at main grain outlet per unit time }(\mathrm{kg})}{\text { whole material at main outlet per unit time }(\mathrm{kg})} \times 100
$$

\section{Threshing capacity}

Threshing capacity (output capacity) is the weight of grains (whole and damaged) threshed and received per hour at the main grain outlet. At the end of each test, total threshed grain was collected from the main grain outlet. Similarly, for manual threshing, output capacity was determined by collecting and weighing all threshed grains within the wooden box. The threshing capacity was calculated using Equation 7 according to Smith et al. (1994).

$$
\text { Threshing capacity }(\mathrm{kg} / \mathrm{h})=\frac{\text { threshed grains at main outlet }(\mathrm{kg})}{\text { duration of test run }(\min )} \times 60
$$

\section{Fuel consumption}

Fuel consumption was measured by filling the engine fuel tank completely at the start and finish of each harvesting period and recording the quantity of fuel added (Smith et al., 1994; Amponsah et al., 2014). A graduated measuring cylinder was used for the refilling. Fuel consumption was calculated on the basis of litres of fuel consumed per hour of machine operation.
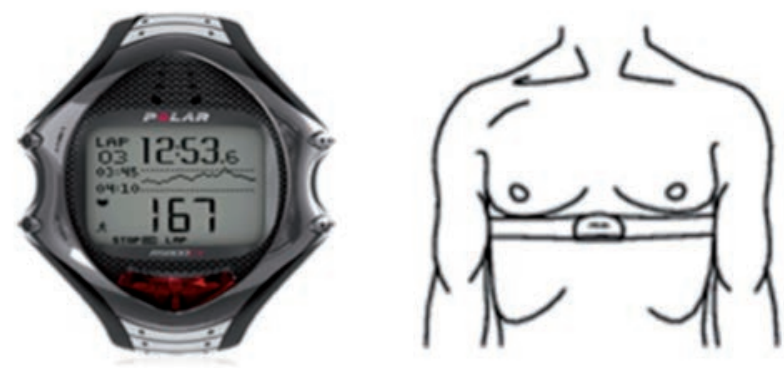

Figure 3. The Polar (RS 800) watch and chest strap as worn by a person.

\section{Harvesting drudgery}

A Polar heart rate sensing device (RS 800) was used to obtain the heart rate of the operator during experimental trials with the Yanmar DB 1000 paddy thresher and manual threshing with the wooden box. Figure 3 shows the Polar heart rate (RS 800) watch and how the chest strap (with heart beat sensor) should be worn before an activity (Amponsah et al., 2014).

Before and after each physical activity, the person is allowed 10-min period of rest so the heart rate could be stabilised which are referred to as the rest and recovery periods respectively. Using the mean heart rate obtained for a specific physical activity to trace for a corresponding energy consumption value on the heart rate-energy conversion chart (Jones, 1988), the gross energy consumed (Watts) was determined.

\section{Economic feasibility assessment}

The cost of threshing (both mechanised and manual methods) was calculated by considering the fixed and variable costs. Fixed (ownership) costs include depreciation, interest, taxes, insurance, and shelter. Operating costs on the other hand, include repairs and maintenance, fuel, lubrication and operator charge. Total cost of the machine is the sum of its total fixed costs and total variable costs. Depreciation on mechanised thresher was calculated using the straight line method according to Hunt (1983) using Equation 8 whilst the interest on machine ownership was calculated using Equation 9.

$$
\begin{aligned}
& \text { Depreciation }=\frac{\text { Purchase price }- \text { salvage price }}{\text { Economic life }} \\
& \text { Interest }=\text { Rate }\left(\frac{\text { Purchase price }+ \text { salvage price }}{2}\right)
\end{aligned}
$$

Taxes, insurance and shelter are usually $1.0 \%$ of purchase price. Where $0.5 \%$ each of purchase price is allocated to insurance and shelter and $0 \%$ of purchase price for taxes (Hunt, 1983). Fuel cost depends on thresher's fuel consumption $\left(\mathrm{Lha}^{-1}\right)$, cost of fuel $\left(\mathrm{US} \$ 1^{-1}\right)$, threshing capacity $\left(\mathrm{kgh}^{-1}\right)$ and working hours per year. Lubricant cost is usually calculated as $15 \%$ of fuel cost unless lubricant consumption $\left(\mathrm{Lha}^{-1}\right)$ is otherwise stated (Kepner et al., 1982). Repairs and Maintenance (R\&M) cost is usually 5\% of machinery purchase cost per annum while labour cost depends on the number of farm hands required to complete a specific harvesting task and the rate charged per hectare (Hanna, 2001).

Based on calculated total cost of threshing and assumed per hour hiring cost, the expected revenue, profit and break-even cost were determined for each threshing method as used in (Fairhurst, 2012).

\section{Experimental design}

The results of paddy threshing trials and field measurements were statistically analysed as a split plot layout in randomised complete block design with 3 replicates, using GenStat Discovery Edition 3 (VSN International, 2011). In the comparative assessment of both manual and mechanised threshing options, main plot treatment was the threshing method and rice variety was the subplot treatment. However, in the analysis of the mechanised thresher performance, the main plot treatment was the rice variety whereas drum speed or feed rate was the subplot treatment. The least significant difference was used at the $\mathrm{P}<0.05$ level of probability to test difference between treatment means. Analysis of variance was 
performed to determine the effects of drum speed and feed rate and their interaction on threshing quality and rate of work.

\section{Results and discussion}

\section{Crop condition}

Table 2 shows details of crop condition for Amankwatia and AGRA rice varieties before mechanised and manual threshing operations.

From Table 2, it could be seen that except for percentage grain damage, Amankwatia variety recorded greater values for all other parameters (grain moisture, straw moisture, grain-straw ratio, grain diameter, grain length and crop height) than AGRA rice variety.

\section{Performance evaluation}

Graph in Figure 4A shows the mean threshing and cleaning efficiencies of the Yanmar DB 1000 mechanised paddy thresher at varying feed rates. Threshing efficiency increased from $94.6 \%$ to $95.8 \%$ with increasing paddy feed rate from $200 \mathrm{kgh}^{-1}$ to $600 \mathrm{kgh}^{-1}$ with no significant $(\mathrm{P}<0.05)$ difference observed irrespective of drum peripheral speed and rice variety.

This could be explained based on the fact that with an increase in feed rate, more paddy gets into the machine's threshing unit to be threshed per unit time. This trend agrees with studies by AboEl-Naga et al. (2015) on evaluation of a lentil thresher. Conversely, cleaning efficiency decreased significantly from $84.2 \%$ to $81.6 \%$ as feed rate increased from $200 \mathrm{kgh}^{-1}$ to $600 \mathrm{kgh}^{-1}$. This could be due to the reason that increased feed rate poses extra pressure on the machine's blower unit causing substantial amount of materials other than grain coming out into the main grain outlet. This agrees with studies by Singh et al. (2015) on evaluation of a multi millet thresher.

Figure $4 \mathrm{~B}$ is a graph showing threshing efficiency of the Yanmar DB 1000 mechanised paddy thresher at varying drum rotational speed.

The greatest significant $(\mathrm{P}<0.05)$ threshing efficiency of $96.5 \%$ was recorded at a drum speed of $650 \mathrm{rpm}$ while the least $(93.8 \%)$ was recorded at a drum speed $550 \mathrm{rpm}$. The threshing efficiency increased with increasing drum rotational speed, irrespective of feed rate and rice variety. This could be attributed to the fact that with higher drum rotational speed, there's high impact from threshing teeth ensuring more grains are threshed per unit time. This trend agrees with studies by Olaye et al. (2016) on evaluation of an axial-flow rice thresher, El-Haddad (2000) on evaluation of simple grain threshers and Singh et al. (2015) on the evaluation of a multi millet thresher.
Table 3 illustrates the mean percentage grain loss by weight recorded by the mechanised thresher under varying drum speed and paddy feed rate. The mechanised thresher recorded the greatest significant $(\mathrm{P}<0.05)$ grain loss of $7.07 \%$ at a drum speed of 650 $\mathrm{rpm}$ whereas the least $(4.80 \%)$ was at $550 \mathrm{rpm}$, irrespective of rice variety.

Similarly, the greatest significant grain loss (6.93\%) was recorded at a paddy feed rate $600 \mathrm{kgh}^{-1}$ whilst the least $(4.95 \%)$
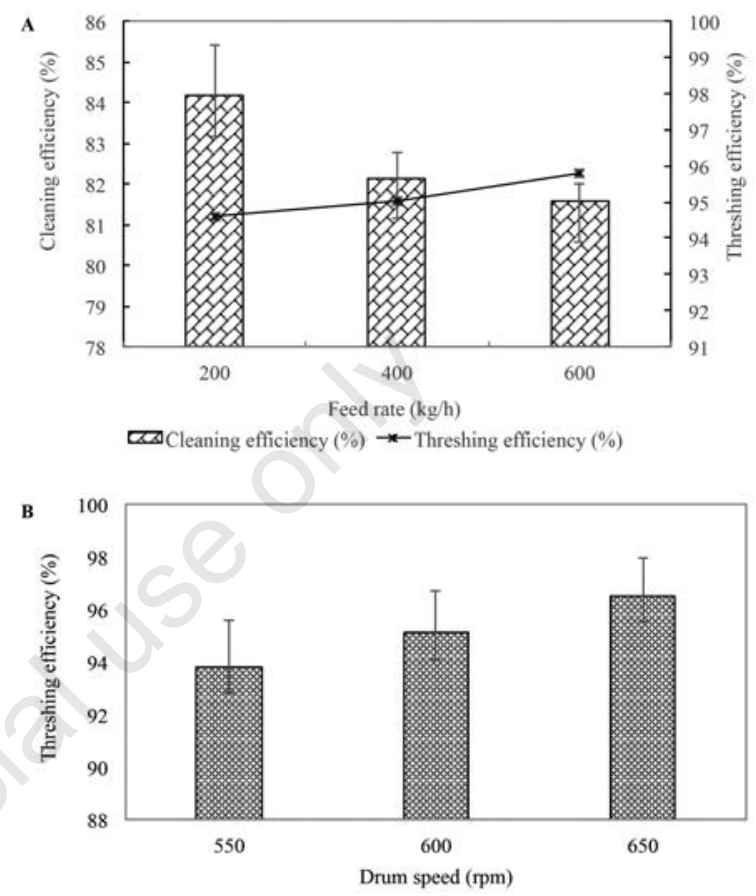

Figure 4. A) Threshing and cleaning efficiencies of the mechanised thresher at varying feed rates; B) Threshing efficiency of the mechanised thresher at varying drum speed.

Table 2. Crop condition at threshing.

\begin{tabular}{lcc} 
Parameter/crop variety & Amankwatia & AGRA \\
Grain moisture content (\% w.b) & 18.0 & 16.9 \\
Straw moisture content (\% w.b) & 20.5 & 19.6 \\
\hline Grain-straw ratio & 1.27 & 1.23 \\
Grain diameter (mm) & 2.69 & 2.57 \\
\hline Grain damage (\%) & 0.10 & 2.15 \\
Grain length (mm) & 9.87 & 9.39 \\
\hline Crop height (cm) & 127 & 126 \\
\hline
\end{tabular}

Table 3. Mean grain loss (\%) and mean fuel consumption as influenced by drum speed and feed rate.

\begin{tabular}{lccccc}
$\begin{array}{l}\text { Drum speed } \\
(\mathrm{rpm})\end{array}$ & $\begin{array}{c}\text { Grain loss } \\
(\%)\end{array}$ & $\begin{array}{c}\text { Fuel consumption } \\
\left(\mathrm{Hh}^{-1}\right)\end{array}$ & $\begin{array}{c}\text { Feed rate } \\
\left(\mathrm{kgh}^{-1}\right)\end{array}$ & $\begin{array}{c}\text { Grain loss } \\
(\%)\end{array}$ & $\begin{array}{c}\text { Fuel consumption } \\
\left(\mathrm{Lh}^{-1}\right)\end{array}$ \\
550 & $4.80^{\mathrm{c}}$ & $0.37^{\mathrm{c}}$ & 200 & $4.95^{\mathrm{c}}$ & $0.31^{\mathrm{c}}$ \\
600 & $5.90^{\mathrm{b}}$ & $0.42^{\mathrm{b}}$ & 400 & $5.86^{\mathrm{b}}$ & $0.40^{\mathrm{b}}$ \\
\hline 650 & $7.07^{\mathrm{a}}$ & $0.46^{\mathrm{a}}$ & 600 & $6.93^{\mathrm{a}}$ & $0.54^{\mathrm{a}}$ \\
LSD & 0.68 & 0.03 & LSD & 0.68 & 0.03 \\
\hline CV (\%) & 21.9 & 26.7 & $\mathrm{CV} \mathrm{( \% )}$ & 22.3 & 13.3 \\
\hline
\end{tabular}

*Values followed by the same letter in the same column are not significantly different at $\mathrm{P}<0.05$. LSD, least significant difference; CV, coefficient of variation. 
was at $200 \mathrm{kgh}^{-1}$. Studies by Akolgo et al. (2015) recorded an average grain loss of $9.4 \%$ during loss evaluation of the Yanmar DB 1000 paddy thresher for Jasmine 85 rice variety.

Graph in Figure 5 depicts the percentage broken grains and grain loss by weight as influenced by drum rotational speed and paddy feed rate for the Yanmar DB 1000 mechanised thresher.

The percentage broken grain and grain loss both increased significantly $(\mathrm{P}<0.05)$ with increasing drum speed for all feed rate levels. This is because as drum speed is increased, there is increased impact force on the grains to aid threshing which causes significant breakage on some of the grains. Also, more power is delivered to the blower unit with increased drum speed so as to generate more air stream. The increased air stream blows some of the grains away through the sieve outlet, causing significant losses.

Similarly, percentage broken grains and grain loss increased steadily with increasing feed rate, irrespective of drum speed and rice variety. Again, percentage broken grains ranged from $0.06 \%$ to $2.5 \%$ across various drum speeds and feed rates. Akolgo et al. (2015) recorded percentage broken grains ranging from $0 \%$ to 2.2\% during evaluation of the Yanmar DB 1000 thresher for Jasmine 85 rice variety. It must be stated that there was no significant difference $(\mathrm{P}<0.05)$ in percentage grain loss at various feed rates. Conversely, there were significant differences in percentage broken grains at various feed rates. This trend might be due to the fact that more seed received impact from cylinder teeth and blower impeller as crop throughput was increased resulting in an increase in internal friction and number of blown or lost grains respectively. The trend of increasing broken grains and grain loss with increasing feed rate and drum speed agrees with studies by Olaye et al. (2016), Akolgo et al. (2015) and Emara (2006).

Table 3 illustrates also the mean fuel consumption at varying drum speed and feed rate during mechanical threshing with the Yanmar DB 1000 paddy thresher for the two rice varieties.

From Table 3, the highest fuel consumptions of $0.46 \mathrm{Lh}^{-1}$ and $0.54 \mathrm{Lh}^{-1}$ were respectively recorded at $650 \mathrm{rpm}$ drum speed and $600 \mathrm{kgh}^{-1}$ feed rate; whereas at $550 \mathrm{rpm}$ drum speed and $200 \mathrm{kgh}^{-1}$ feed rate, the least fuel consumptions of $0.37 \mathrm{Lh}^{-1}$ and $0.31 \mathrm{Lh}^{-1}$ were respectively recorded. Again, it was realised that fuel consumption increased significantly $(\mathrm{P}<0.05)$ with increasing drum speed and feed rate, which is in agreement with studies by Olaye et al. (2016), Abo-El-Naga et al. (2015) and Emara (2006). This trend could be explained based on the fact that at higher drum speeds and crop throughput, threshing power requirement increases, translating into increased fuel required by the engine to provide the needed power.

Figure 6A depicts the physical power requirement for mechanised threshing with the Yanmar DB 1000 paddy thresher at varying feed rates. The greatest significant $(\mathrm{P}<0.05)$ power requirement of $672 \mathrm{~W}$ was recorded when operating the thresher at a feed rate of $600 \mathrm{kgh}^{-1}$, while the least $(580 \mathrm{~W})$ was realised at a feed rate of $200 \mathrm{kgh}^{-1}$.

Again, power requirement increased with increasing feed rate. This is because increasing crop throughput results in higher physical power consumption due to increased heart rate.

Figure $6 \mathrm{~B}$ presents the mean threshing capacity for the Yanmar DB 1000 mechanised thresher at varying crop feed rate and drum speed.

At a drum speed of $550 \mathrm{rpm}$, threshing capacity increased from $73.4 \mathrm{kgh}^{-1}$ to $216.1 \mathrm{kgh}^{-1}$ as feed rate increased from $200 \mathrm{~kg} / \mathrm{h}$ to $600 \mathrm{~kg} / \mathrm{h}$. Again, at $600 \mathrm{rpm}$ drum speed, threshing capacity increased from $82.8 \mathrm{kgh}^{-1}$ to $235.1 \mathrm{kgh}^{-1}$ with increasing feed rate from $200 \mathrm{~kg} / \mathrm{h}$ to $600 \mathrm{~kg} / \mathrm{h}$. Lastly, at $650 \mathrm{rpm}$ drum speed, threshing capacity increased from $90.1 \mathrm{kgh}^{-1}$ to $257 \mathrm{kgh}^{-1}$ with increas- ing feed rate from $200 \mathrm{~kg} / \mathrm{h}$ to $600 \mathrm{~kg} / \mathrm{h}$.

From graph in Figure 6B, it could be deduced that irrespective of drum speed, threshing capacity increased significantly with increasing feed rate. Similarly, threshing capacity increased with increasing drum speed at all feed rate levels. The increasing threshing capacity with increasing feed rate and drum speed could be attributed to the fact that at higher rotational speed and crop throughput, there is increased impact on grains and quantity of crops in the machine's threshing unit respectively. Consequently, more grains can be threshed per unit time. This trend agrees with studies by Badway (2002) and Olaye et al. (2016).

Table 4 illustrates the performance of the Yanmar DB 1000

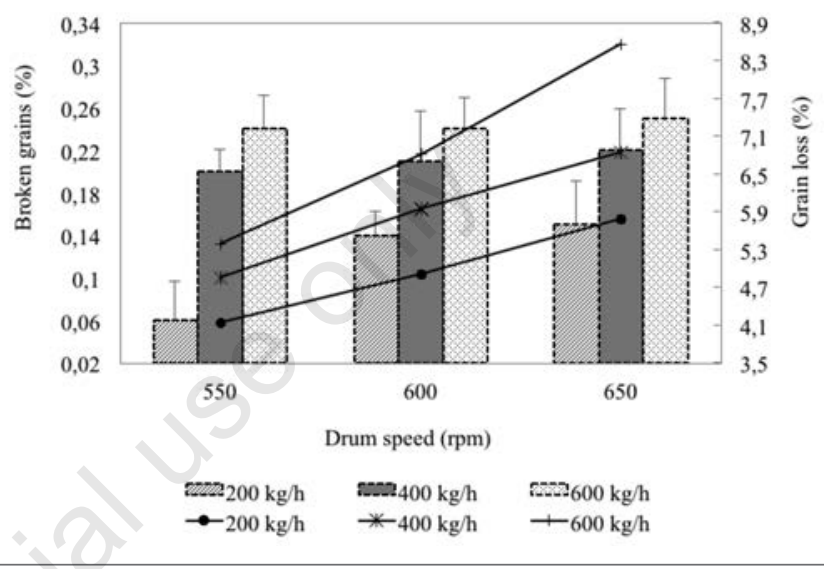

Figure 5. Mean broken grains (\%) and grain loss (\%) at varying drum speed and feed rate.
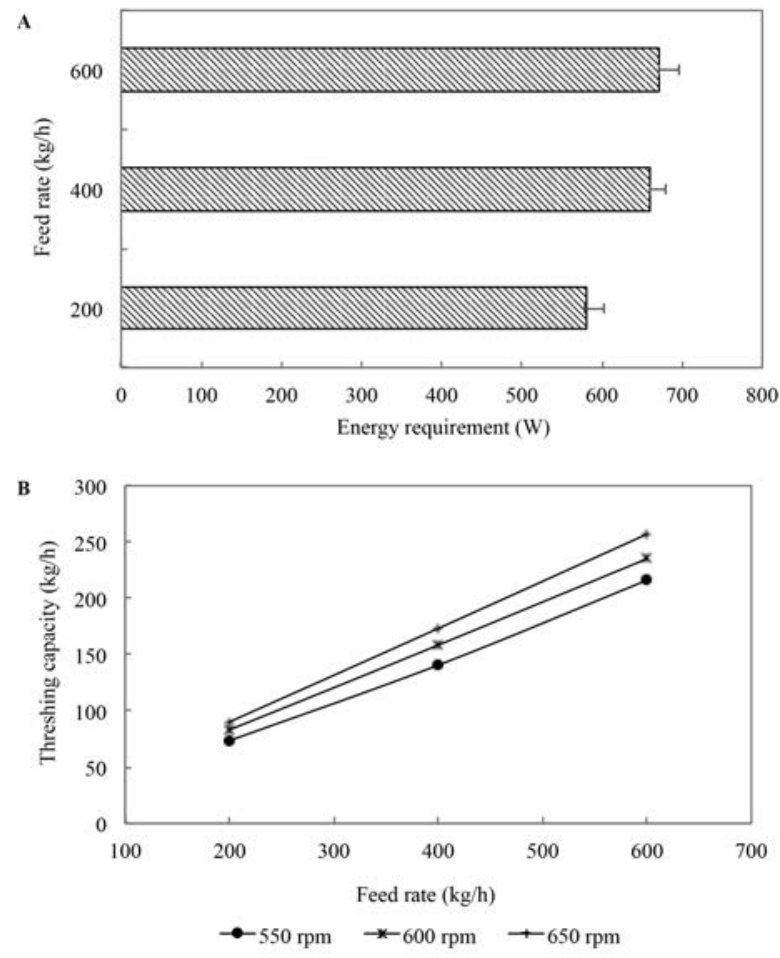

Figure 6. A) Physical power requirement for mechanised threshing at varying feed rate; $B$ ) Threshing capacity as influenced by crop feed rate and drum speed. 
paddy thresher for Amankwatia and AGRA rice varieties at manufacturer's operating recommendation (600 rpm drum speed and $400 \mathrm{kgh}^{-1}$ feed rate).

From Table 4, it could be seen that AGRA rice variety recorded significantly greater values for cleaning efficiency, threshing efficiency and threshing capacity than Amankwatia. Conversely, Amankwatia variety was associated with significantly greater $(\mathrm{P}<0.05)$ levels of grain loses, broken grains, fuel and physical power requirements than AGRA rice variety. This situation could be attributed to the fact that at the time of threshing (from Table 2), grain-straw ratio and crop moisture for Amankwatia was relatively higher than AGRA. Besides, it was realised from field observation that AGRA variety was easier to shatter than Amankwatia under similar conditions. Studies by FAO (1976) indicated that threshing is affected by grain shatterability and moisture content. Singh et al. (2015) reported a decrease in threshing efficiency at higher crop moisture content. Higher cleaning efficiency at lower crop moisture was also reported by Bansal and Lohan (2009).

Table 5 illustrates the performance of manual paddy threshing by impact method using the wooden box for threshing Amankwatia and AGRA rice varieties. Average broken grains after threshing ranged from $0.16 \%$ to $0.18 \%$ for AGRA and Amankwatia rice varieties respectively with no significant difference in percentage broken grains between rice varieties. Average grain loss showed significant difference between rice varieties while ranging from $6.06 \%$ to $8.35 \%$ for AGRA and Amankwatia respectively.
This was because Amankwatia naturally has poor shattering properties than AGRA rice, thus it was easier with few beatings on the wooden box to separate grains for AGRA than Amankwatia. Moreover, crop moisture at threshing for Amankwatia was higher than AGRA rice variety, thus some grains still remained on the panicles after threshing, causing the substantial amount of loss realised for Amankwatia. The above reasons could as well justify the significantly $(\mathrm{P}<0.05)$ lower threshing capacity and the relatively higher physical power demand in threshing Amankwatia than AGRA rice variety. However, unlike threshing capacity, physical power demand for threshing showed no significant difference $(\mathrm{P}<0.05)$ between AGRA and Amankwatia rice varieties in the range of $728 \mathrm{~W}$ to $767 \mathrm{~W}$ respectively. Better efficiency of manual threshing is achieved with the AGRA rice variety than Amankwatia.

Table 6 depicts the percentage broken grains and grain loss by weight, average physical power demand and threshing capacity for manual threshing by impact using the wooden box and the mechanised threshing with the Yanmar DB 1000 paddy thresher.

Results in Table 6 shows that mechanised threshing was significantly $(\mathrm{P}<0.05)$ better at reducing grain loss and physical power demand whilst yielding higher threshing capacities (more than twice) than manual threshing by impact using the wooden box. However, in terms of reduction in average broken grains, manual threshing by impact with the wooden box was significantly $(\mathrm{P}<0.05)$ better than mechanised threshing with the Yanmar DB 1000 paddy thresher. This could be attributed to the lower impact

Table 4. Performance of the Yanmar DB 1000 paddy thresher as influenced by rice variety at manufacturer's recommended drum speed and feed rate.

\begin{tabular}{|c|c|c|c|c|c|c|c|}
\hline Variety & $\begin{array}{c}\text { Cleaning } \\
\text { efficiency } \\
(\%)\end{array}$ & $\begin{array}{c}\text { Threshing } \\
\text { efficiency } \\
(\%)\end{array}$ & $\begin{array}{l}\text { Grain } \\
\text { loss } \\
(\%)\end{array}$ & $\begin{array}{l}\text { tion par: } \\
\text { Broken } \\
\text { grains } \\
(\%)\end{array}$ & $\begin{array}{c}\text { Threshing } \\
\text { capacity } \\
\left(\mathrm{kgh}^{-1}\right)\end{array}$ & $\begin{array}{c}\text { Fuel } \\
\text { consumed } \\
\left(\mathrm{Lh}^{-1}\right)\end{array}$ & $\begin{array}{l}\text { Power } \\
\text { required } \\
\text { (W) }\end{array}$ \\
\hline AGRA & 87.9 & 96.3 & 5.05 & 0.18 & 170.3 & 0.38 & 615 \\
\hline Amankwatia & 77.4 & 94.0 & 6.79 & 0.20 & 146.8 & 0.45 & 672 \\
\hline LSD & 1.47 & 0.83 & 0.72 & 0.02 & 8.60 & 0.03 & 12.0 \\
\hline CV (\%) & 3.4 & 1.1 & 21.9 & 36.4 & 42.5 & 26.7 & 7.4 \\
\hline
\end{tabular}

$\mathrm{LSD}$, least significant difference; $\mathrm{CV}$, coefficient of variation.

Table 5. Performance of manual threshing by impact method (using the wooden box) for Amankwatia and AGRA rice varieties.

\begin{tabular}{lcccc} 
Variety & & \multicolumn{3}{c}{ Evaluation parameter } \\
& Broken grains (\%) & Grain loss (\%) & Power requirement (W) & Threshing capacity (kgh-1) \\
AGRA & 0.18 & 6.06 & 728 & 120.5 \\
Amankwatia & 0.16 & 8.35 & 767 & 102.9 \\
\hline LSD & $\mathrm{ns}$ & 1.79 & $\mathrm{~ns}$ & 9.66 \\
CV (\%) & 32.6 & 19.8 & 5.1 & 9.3 \\
\hline
\end{tabular}

LSD, least significant difference; CV, coefficient of variation; ns, not significant.

Table 6. Comparative evaluation of manual and mechanised paddy threshing methods.

\begin{tabular}{lcccc}
$\begin{array}{l}\text { Threshing } \\
\text { method }\end{array}$ & Broken grains (\%) & Grain loss (\%) & Power requirement (W) & Threshing capacity (kgh-1) \\
Manual & 0.13 & 8.46 & 834 & 64.9 \\
Mechanised & 0.21 & 5.95 & 660 & 158.4 \\
\hline LSD & 0.06 & 1.79 & 91.2 & 9.66 \\
CV (\%) & 27.7 & 18.7 & 9.2 & 6.5 \\
\hline
\end{tabular}

LSD, least significant difference; $\mathrm{CV}$, coefficient of variation. 
on grains against the wooden surface of the box compared to the metallic cylinder and concave in the case of mechanised threshing. This confirms the fact that mechanised paddy threshing options generally offer better solution to reducing production cost and enhancing labour productivity than manual threshing methods which agrees with report by Alizadeh and Allameh (2013).

\section{Economics of manual and mechanical threshing}

Table 7 shows the total cost of mechanised threshing using the Yanmar DB 1000 paddy thresher and manual threshing using the wooden box based on relevant assumptions. At an investment cost of US\$2000.00, mechanised threshing offered a total annual cost of US\$ 1287.00 while the manual threshing option, at an investment cost of US\$100.00, yielded a total cost of US\$ 746.00 per annum. Making reference to threshing capacity values in Table 6, the total cost per kilogram of threshed paddy for mechanised and manual threshing options were estimated at US\$ 0.008 and US\$ 0.011 respectively.

Figure 7 illustrates the break-even chart for mechanised threshing and manual threshing methods using the Yanmar DB 1000 thresher and the wooden box respectively. Break-even calculation was based on the assumption that cost of threshing was US\$ 3.00 and US\$ 1.00 per hour for mechanised and manual options respectively for a maximum of $1000 \mathrm{~h}$ of work per annum. Cost of paddy threshing values used were prevailing service charges within the study location as at September, 2016.

Mechanised threshing offered greater total annual cost and revenue than the manual threshing option. At $1000 \mathrm{~h}$ of annual use, the mechanised Yanmar DB 1000 paddy thresher is yielding total revenue of US\$ 1712.72 as compared to US\$ 253.75 for manual threshing with the wooden box. The break-even for manual threshing was at $73 \mathrm{~h}$ of machine use (equivalent to 4.74 metric tonnes of threshed paddy) as compared to mechanised threshing at $190 \mathrm{~h}$ (equivalent to 30.10 metric tonnes of threshed paddy). However, the profit margin for the mechanised threshing was over $500 \%$ higher than the manual threshing option.

\section{Conclusions}

The following conclusions based on set objectives could be drawn from the study:

- Threshing efficiency increased significantly from $94.6 \%$ to $95.8 \%$ while cleaning efficiency decreased from $84.2 \%$ to $81.6 \%$ with increasing feed rate irrespective of rice variety. Again, threshing efficiency increased with increasing drum rotational speed, irrespective of feed rate and rice variety.

- Percentage broken grain and grain loss both increased with increasing peripheral drum speed and paddy feed rate irrespective of rice variety. Average fuel consumption and threshing capacity increased significantly with increasing drum speed and feed rate. Similarly, physical energy requirement for threshing increased with increasing paddy feed rate, irrespective of rice variety.

- Crop moisture content and shattering ability had an influence on the threshing efficiency, threshing capacity, grain loss, broken grain, fuel and physical energy requirement at threshing. AGRA rice variety generally performed better than Amankwatia under both mechanical and manually threshing methods.

- Mechanised threshing was significantly better at reducing grain loss and physical energy demand whilst yielding over
$200 \%$ higher threshing capacity than manual threshing by impact using the wooden box.

- Mechanised threshing was financially rewarding, yielding over $500 \%$ higher profit margin than the manual threshing option.

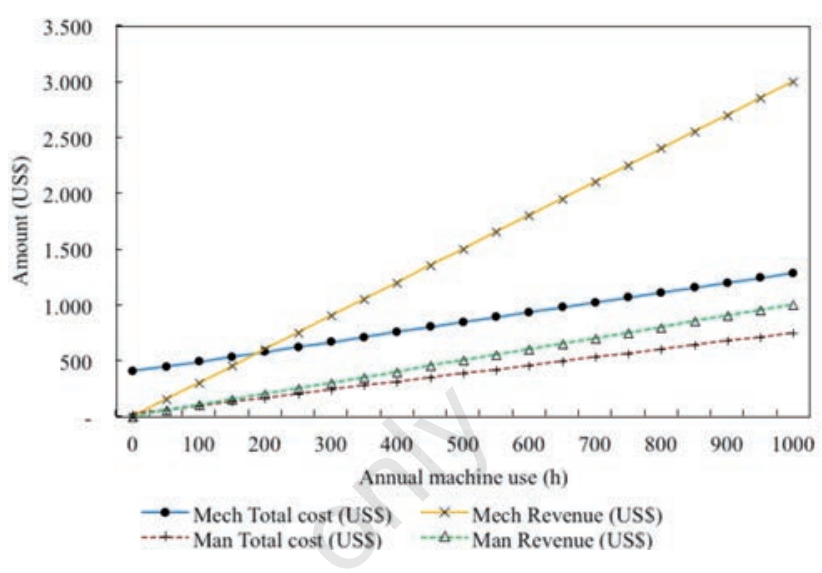

Figure 7. Break-even chart for mechanised (Mech) and manual (Man) paddy threshing options.

Table 7. Total cost for mechanised and manual paddy threshing options.

\begin{tabular}{|c|c|c|c|}
\hline Item & Unit & $\begin{array}{l}\text { Mechanised } \\
\text { thresher }\end{array}$ & $\begin{array}{c}\text { Wooden } \\
\text { box }\end{array}$ \\
\hline Purchase price & US\$ & 2000 & 100 \\
\hline Salvage value & US\$ & 200 & 10 \\
\hline Economic life* & $\mathrm{y}$ & 5 & 5 \\
\hline Depreciation & ${\mathrm{US} \$ \mathrm{y}^{-1}}^{-1}$ & 360 & 18 \\
\hline Interest & ${\mathrm{US} \$ \mathrm{y}^{-1}}^{-1}$ & 22 & 1.1 \\
\hline Insurance & ${\mathrm{US} \$ \mathrm{y}^{-1}}^{-1}$ & 10 & 0.5 \\
\hline Tax & 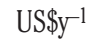 & 0 & 0 \\
\hline Shelter & ${\mathrm{US} \$ \mathrm{y}^{-1}}^{-1}$ & 10 & 0.5 \\
\hline Total fixed cost & 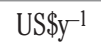 & 402 & 20.1 \\
\hline Fuel (Diesel) cost & US\$1 $1^{-1}$ & 0.91 & - \\
\hline Fuel consumption & l/h & 0.42 & - \\
\hline Annual machine use & $\mathrm{h}$ & 1000 & 1000 \\
\hline Lubricant consumption & $\mathrm{Lh}^{-1}$ & 0.01 & - \\
\hline Lubricant cost & US\$1 $1^{-1}$ & 4.25 & - \\
\hline Worker's salary & US\$ & 75 & 75 \\
\hline Number of workers & & 1 & 2 \\
\hline Fuel & $\mathrm{US} \$ \mathrm{~h}^{-1}$ & 0.38 & - \\
\hline Lubricant & ${\mathrm{US} \$ \mathrm{~h}^{-1}}^{-1}$ & 0.04 & - \\
\hline Repairs and maintenance & $\mathrm{US} \mathrm{h}^{-1}$ & 0.10 & 0.01 \\
\hline Labour & 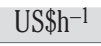 & 0.36 & 0.72 \\
\hline Total variable cost & $\mathrm{US} \mathrm{h}^{-1}$ & 0.89 & 0.73 \\
\hline Total variable cost & US\$y-1 & 885 & 726 \\
\hline Total cost & $\mathrm{US} \$ \mathrm{y}^{-1}$ & 1287 & 746 \\
\hline Total cost & US\$ $\mathrm{kg}^{-1}$ & 0.008 & 0.011 \\
\hline
\end{tabular}

*Estimation was based on survey data provided by rice farmers within the study location. 


\section{Recommendations}

The following recommendations are suggested:

- Further research to determine the optimum crop moisture content for improved rice threshing should be conducted for different varieties.

- Rice breeding programmes should focus future work on releasing more varieties like the AGRA rice that can facilitate threshing.

- Government and other private sectors should consider investing into mechanised threshers to improve productivity and facilitate national self-sufficiency in rice production.

\section{References}

Abo-El-Naga M.H.M., El-Gendy H.A., Mosa E.H. 2015. Evaluation of locally threshing machine performance for threshing lentil crop. Misr J. Agric. Eng. 22:376-88.

Ajav E.A., Adejumo B.A. 2005. Performance evaluation of an Okra thresher. Agric. Eng. Int. CIGR Ejournal VII: PM 04006.

Akolgo G.A., Josiah M.N., Mahama A.A. 2015. Field evaluation of rice losses of the Yanmar DB 1000 thresher in Ghana. J. Ghana Sci. Assoc. 16:26-33.

Alizadeh M.R., Allameh A. 2013. Evaluating rice losses in various harvesting practices. Int. Res. J. Appl. Basic Sci. 4:894-901.

Alizadeh M.R., Bagheri I. 2009. Field performance evaluation of different rice threshing methods. Int. J. Nat. Eng. Sci. 3:139-43.

Amponsah S.K., Bobobee E.Y.H., Agyare W.A., Okyere J.B., Aveyire J., King S.R. 2014. Mechanical cassava harvesting as influenced by seedbed preparation and cassava variety. Appl. Eng. Agric. 30:391-403.

Angelucci F., Asante-Poku A., Anaadumba P. 2013. Analysis of incentives and disincentives for rice in Ghana: Technical notes series. MAFAP, FAO, Rome, Italy.

Appiah F., Guisse R., Dartey P.K. 2011. Post harvest losses of rice from harvesting to milling in Ghana. J. Stored Prod. Postharvest Res. 2:64-71.

Badway M.E. 2002. Modification and evaluation of paddy rice thresher to suit flax deseeding. Misr J. Agr. Eng. 19:881-900.

Bansal N.K., Lohan S.K. 2009. Design and development of an Axial flow thresher for seed crops. J. Agric. Eng. 46:1-8.

Campbell R., Schiff H., Snodgrass D., Neven D., Downing J., Sturza D. 2009. Global food security response: West Africa rice value chain analysis - Microreport No. 161. United States Agency for International Development (USAID). Available from: https://www.microlinks.org/sites/microlinks/files/ resource/files/GFSR WA Rice VC Analysis.pdf

El-Haddad W.Z. 2000. A simplified design and performance study of threshing and winnowing machine suitable for sample holdings. M.Sc. Th. Agric. Mech. Fac. of Agric., Kafr El-Sheikh, Tanta Univ., Egypt.

Emara Z.M.I. 2006. Modification of the threshing drum of a stationary thresher to suit separating flax crop. Misr J. Ag. Eng. 23:324-45.

Fairhurst D.S. 2012. Using Excel for business analysis: a guide to financial modelling fundamentals. Wiley Publishing, Hoboken, NJ, USA.

FAO. 1976. Mechanisation of rice production: India-NigeriaSenegal, an international coordinated research project project: 1970-1976. Food and Agriculture Organisation (FAO) of the United Nations, Rome, Italy.

Gol A.K., Nada S.K. 1991. Performance of power operated groundnut pod stripper. Agric. Mech. Asia Africa Lat. Am. 22:25-8.

Hanna M. 2001. Estimating field capacity of field machines. Coop. Ext. Serv. Iowa State Univ. Sci. Technol. PM 696. Available from: https://store.extension.iastate.edu/Product/4032

Hunt D.R. 1983. Farm power and machinery management, 8th ed. Iowa State University Press, Ames, IA, USA.

IDRC. 1976. Rice postharvest technology. International Development Research Centre (IDRC), Ottawa, Canada.

ISSER. 2000. The state of the Ghanaian economy. Inst. Statical Soc. Econ. Res. (ISSER), Univ. Ghana, Legon, Accra, Ghana.

Jones N.L. 1988. Clinical exercise testing, 3rd ed. W.B. Saunders, Philadelphia, PA, USA.

Kepner R.A., Bainer R., Barger E.L. 1982. Principles of farm machinery, 3rd ed. AVI Publishing Comp. Inc., West Port, CT, USA.

Khan A.U. 1971. Harvesting and threshing of paddy. In: International Rice Research Conference, April 19-21. Los Panos, Laguna, Philippines, pp. 19-21.

MoFA. 2009. National rice development strategy (NRDS) - Draft Report. Ministry of Food and Agriculture (MoFA) - The Republic of Ghana. Available from: https://www.jica.go.jp/ english/our_work/thematic_issues/agricultural/pdf/ghana_en.pdf

MoFA SRID. 2011. Agriculture in Ghana - Facts and figures (2010). Ministry of Food and Agriculture (MoFA) - Statistics, Research and Information Directorate (SRID). Available from: http://www.agrihomegh.com/wp-content/uploads/2015/12 /AGRICULTURE-IN-GHANA-Fact-and-Figures-2010.pdf

NRI. 2000. Manual for grain quality and processing: course 3 of grain storage management. Natural Resources Institute (NRI), University of Greenwich, Kent, UK.

Okine C.B. 2014. Ghana to reduce heavy rice imports. Graphic Online. Available from: https://www.graphic.com.gh/business/ business-news/ghana-to-reduce-heavy-rice-imports.htmlK

Olaye A.R.I.B., Moreira J., Hounhouigan J., Amponsah S.K. 2016. Effect of threshing drum speed and crop moisture content on the paddy grain damage in axial-flow thresher (ASI). J. Multidiscip. Sci. Technol. 3:5-11.

Osei-Asare YB. 2010. Mapping of poverty reduction strategy papers (PRSPs), Sector strategies and policies related to rice development in Ghana. Coalition for African Rice Development (CARD) c/o AGRA, Nairobi, Kenya. Available from: https://riceforafrica.net/downloads/CARD \%20DOCS/ Ghana_Mapping_report_Final_version.pdf

Rickman J., Moreira J., Gummert M., Wopereis M.C.S. 2013. Mechanising Africa's rice sector. In: Wopereis M.C.S., Johnson D.E., Ahamdi N., Tollens E., Jalloh A. (Eds.), Realising Africa's rice promise. CAB International, Wallingford, UK, pp. 332-342.

Singh K.P., Poddar R.R., Agrawal K.N., Hota S., Singh M.K. 2015. Development and evaluation of multi millet thresher. J. Appl. Nat. Sci. 7:939-48.

Smith D.W., Sims B.G., O’Neill D.H. 1994. Testing and evaluation of agricultural machinery and equipment: principles and practices. Food and Agriculture Organisation, Rome, Italy.

Špokas L., Steponavičius D., Petkevičius S. 2008. Impact of technological parameters of threshing apparatus on grain damage. Agron. Res. 6:367-76.

VSN International. 2011. GenStat discovery, 3rd edition. Available from: https://www.vsni.co.uk/products/discovery/ 